\title{
Improving the efficiency of mass-exchange between liquid and steam in rectification columns of cyclic action
}

\author{
Yurii Bulii, Anatolii Kuts, Ivan Yuryk, Andrii Forsiuk
}

National University of Food Technologies, Kyiv, Ukraine

Keywords:

Alcohol

Rectification

Plate

Column

Impurities

Article history:

Received 21.07.2020

Received in revised

form 01.02 .2021

Accepted 30.06.2021

Corresponding

author:

Yurii Bulii

E-mail:

yvbuliy@gmail.com

DOI: $10.24263 / 2304-$

974X-2021-10-2-11

\section{Abstract}

Introduction. The purpose of the work was to determine the optimal time of residence of the liquid on the plates, the grade of extraction and concentration ratio of volatile impurities of alcohol and the specific consumption of heating steam in rectification columns of cyclic action.

Materials and methods. The studies were carried out in a rectification column, equipped with flaky plates with a variable free cross-section. Concentration of alcohol volatile impurities was determined by chromatographic method, the grade of their extraction and concentration ratio - by calculation method, other indicators - by commonly known methods.

Results and discussion. The maximum extraction of volatile impurities was being achieved in a rectification column, equipped with flaky plates containing turnaround sections connected to drive mechanisms, the action of which is occurred according to a given algorithm. The optimal parameters of operating the column were: vapor velocity in the orifices of the flakes during the period of liquid retention on the plates $12-14 \mathrm{~m} / \mathrm{s}$; during liquid pouring $1-1.5 \mathrm{~m} / \mathrm{s}$; time of residence of the liquid on the plates $40 \mathrm{~s}$, pouring time $1.7 \mathrm{~s}$; pressure in the lower part of the column $12 \mathrm{kPa}$; the concentration of ethyl alcohol in the still residue $3-4 \%$ vol. In order to provide the cycles, the free sectional area of the plates must change instantaneously from 5.5 to $51.7 \%$. This technical solution allows to provide complete disposal of ethers, methyl acetate and isopropyl alcohol, to increase the grade of extraction of higher alcohols of fusel alcohol and methanol by $38 \%$, the concentration ratio of aldehydes by $25 \%$, higher alcohols by $38 \%$, methanol by $37 \%$, and to reduce specific consumption of heating steam by $40 \%$ compared to a typical column operating in stationary mode.

Conclusion. The innovative technology of cyclic rectification allows to increase the grade of extraction and the concentration ratio of volatile impurities of alcohol by $25-38 \%$ and reduce energy consumption by $40 \%$ compared with the known ones. 


\section{Introduction}

Technical progress in the alcohol industry is inextricably linked to the development and implementation of highly efficient column apparatuses (Shyian et al., 2009; Kyziun et al., 2006) and energy-saving ways of mass transfer between the liquid and steam on their plates (Martseniuk et al., 2019). One of the ways of solving the mass transfer process problem is the use of cyclic mode of phase motion, which is based on alternate change of two periods: the steam passing up the column period and the period of liquid pouring on its plates (Maleta, et al., 2011; Kiss et al., 2012). Implementation of controlled cycles of liquid retention on the plates allows to prolong the time of its contact with steam, to create conditions in order to achieve a phase state close to equilibrium and to bring the efficiency of each real plate closer to the theoretical one (Buliy et al., 2019). This significantly reduces the specific consumption of heating steam, decreases the volume of alcohol-containing waste and minimizes the cost of equipment (Kiss, 2015).

There are well-known ways of increasing the residence time of liquid on the plates by organizing the flow of separate steam-liquid jets with their mutual collision (Pătruţ et al., 2014) or additional installation of baffles and reflectors, directing the steam through the appropriate bypass pipelines, etc. (Krivosheev et al., 2015). Despite the obtained positive results in reducing energy costs, the known methods and apparatuses of cyclic operation have not found wide practical application due to the lack of mass exchange in the steam period (Lita et al., 2012), the steam pressure dependence of pouring devices' operation (Toftegard et al., 2016), the fluctuations of the steam pressure in the collector, the inability to stabilize the hydrodynamic mode of plates (Flodman et al., 2012), the mixing of liquid on adjacent plates during its pouring, the low apparatuses' steam and liquid throughput capacity, and the complexity of constructive solutions (Bastian et al., 2018).

The authors proposed an innovative rectification technology, which excludes earlier mentioned disadvantages (Buliy et al., 2016) and provides periodic liquid pouring from one plate to another at continuous supply of liquid and heating steam into the column (Ukrainets et al., 2018). To implement the technology, the design of a rectification column equipped with plates with variable free cross-section was developed (Bulii et al., 2019). For stable operation of plates in the column hydrodynamic regimes were maintained, providing effective mass transfer between liquid and steam without entrainment of liquid on upper plates during the fluid retention period and its intensive pouring through pouring and barbotage holes after the end of the retention time.

The aim of the work was to study the efficiency of mass-exchange between liquid and steam in column apparatuses of cyclic action: to determine the grade of extraction and the concentration ratio of volatile impurities of alcohol during its extraction from alcoholcontaining fractions and to identify the specific rate of heating steam in the studied rectification column.

\section{Research objectives:}

1. To determine the grade of extraction and the concentration ratio of alcohol impurity concentrations under conditions of typical and cyclic rectification (in columns equipped with moving valves and turning plate sections);

2. To determine the optimal technological parameters of the studied column and the residence time of the liquid on its plates, by which the maximum extraction of volatile impurities is provided without reducing the liquid throughput of the column;

3. To determine the specific rate of heating steam in a rectification column of cyclic action. 


\section{Materials and methods}

\section{Research objects}

\section{Rectification columns of cyclic action with moving valves (RC)}

The RC is made of stainless steel AISI 304, equipped with flaky plates of arched type. Technical characteristics: diameter $-426 \mathrm{~mm}$; number of plates - 30; distance between the plates $-300 \mathrm{~mm}$; the cross-sectional area of flakes' holes $-19,42 \mathrm{~mm}^{2}$; thickness of the plate fabric $-2 \mathrm{~mm}$; free cross-section of the plate: $5,5 \%$ - during the residence of the liquid on the plates $-5,5 \%$; during the liquid pouring $-51,7 \%$.

A fragment of the RC with movable rods, valves and hydraulic shutters is shown in Figure 1a (patent UA 116565. Rectification column with controlled cycles). The operation of the column provided the conducting of the adjustable in time cycles of liquid residence on the plates and its synchronous pouring from one plate to another over the entire height of the column in two successive stages, repeating periodically in time, alternately, according to the specified algorithm without interrupting the liquid and steam supply (patent UA 89874. Method of liquid pouring on plates of column apparatus in the process of mass transfer between steam and liquid). The interval of liquid retention was being determined experimentally depending on the grade of extraction of volatile alcohol impurities and their concentration ratio.

The experimental $\mathrm{RC}$ was included in the scheme of the bragorectificational plant (BRP). The column contained corps 1 , plates 2 with contact elements 3 , movable rods 4 and 5 , on which valves 6 and springs 7 were mounted. The rods moved up and down under the action of drive mechanisms (double-acting pneumatic cylinders of DNT type manufactured by FESTO). At that, valves 6 closed and opened the holes of pouring pipes 8 alternately. The operation of pneumatic cylinders was managed in accordance with the M340 controller program of 'Schneider Electric' company. Pipes 8 were inserted into sleeves 9 and together with them served as water traps, which prevented steam breakthrough through all the holes during liquid pouring.

Figure $1 \mathrm{~b}$ shows an experimental $\mathrm{RC}$ with movable rods and valves without hydraulic shutters (patent UA 139228. Column mass-exchange apparatus of cyclic action). The technical solution allowed one-stage (full) and two-stage methods of liquid pouring on plates (Figure 2). The one-step method involved pouring all the liquid from one plate to another (Figure 2a). According to the two-stage method (patent UA 141245. Method of pouring the liquid on the plates of mass-exchange column apparatus) part of the liquid had been pouring from the upper plate to the lower one (30-70\% of its volume), and after a specified delay time, its remnants were poured (Figure $2 b$ ).

\section{Plant for ethyl alcohol extraction from alcohol-containing fractions}

The scheme of the implementation of the studied RC into the BRP one is shown in Figure 3.

The plant included the experimental column 6, the upper and lower parts of which are connected to the vacuum breakers 4 , evaporator 5 , dephlegmator 7 , condenser 8 , alcoholcollecting vessel (trap) 9, softened water collector 1 , intermediate collectors of still residue 15 and alcoholic fractions 18 , flow-meters $3,11,12$ and 13 , centrifugal pumps 2, 16, 17 and decantator 10 . 

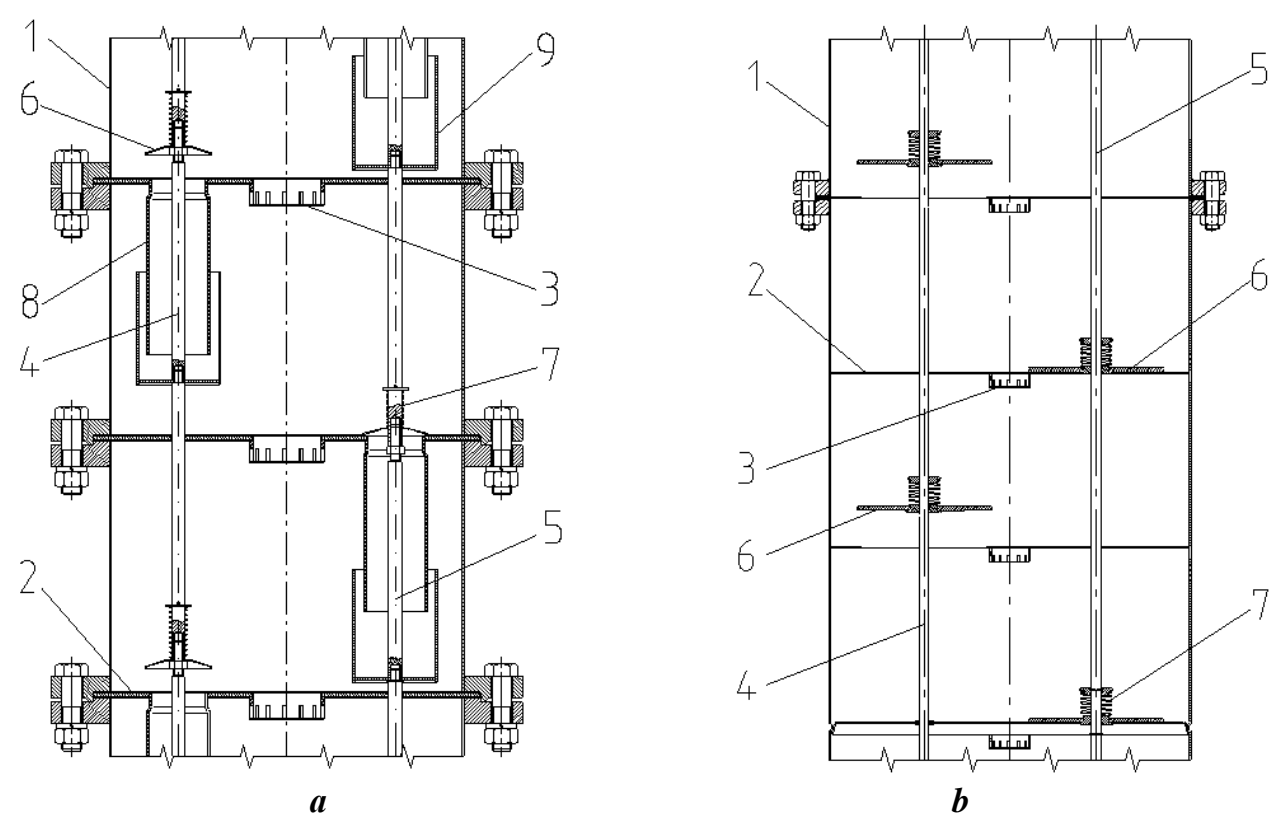

Figure 1. Fragments of the studied RC with movable valves: with hydraulic shutters $(a)$ and without hydraulic shutters $(b)$ : 1 - body; 2 - plates; 3 - contact devices; 4,5 - rods; 6 - valves; 7 - springs; 8 - pouring pipes; 9 - sleeve.
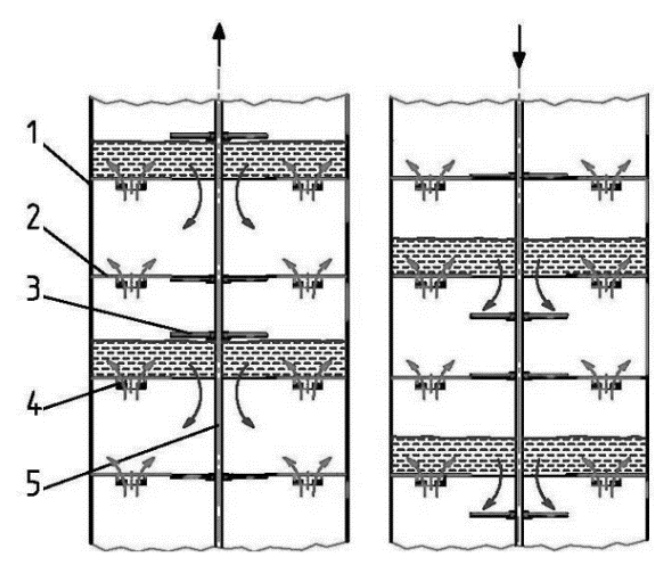

$a$
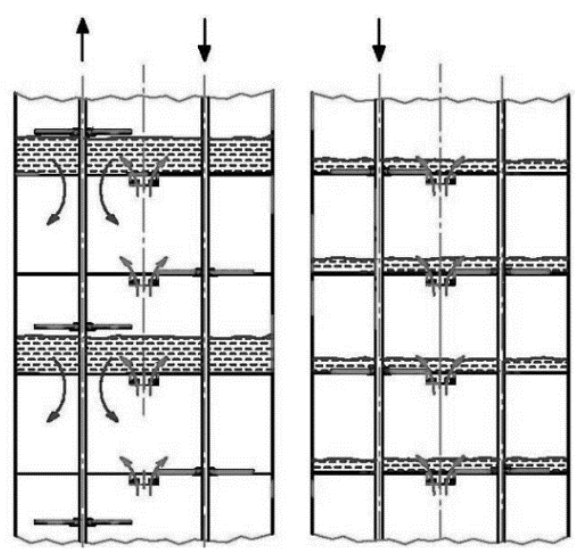

$b$

Figure 2. One-stage and two-stage methods of liquid pouring on the plates of the cyclic action RC:

1 - body; 2 - plate; 3 - valve; 4 - contact element; 5 - moving rod. 


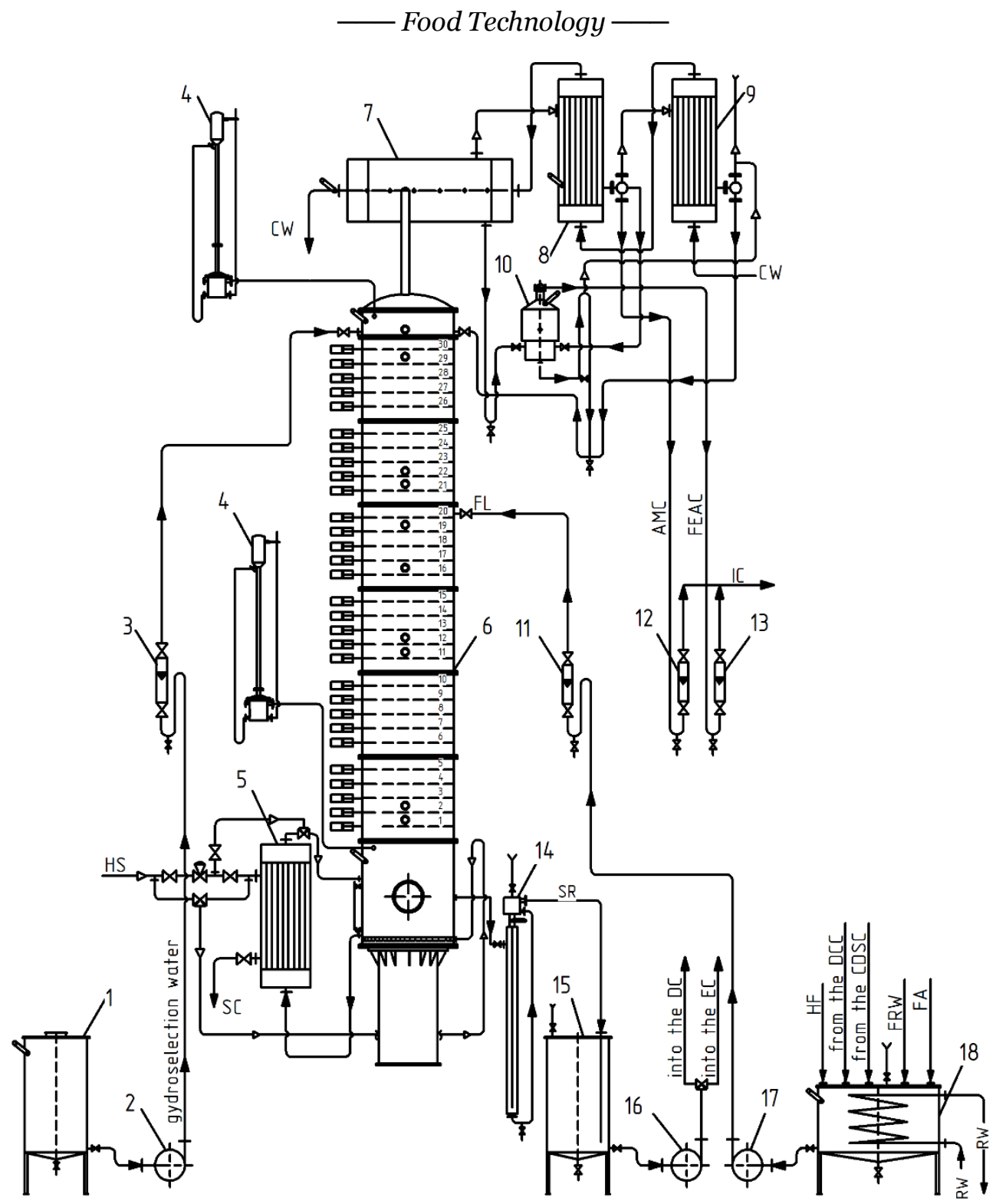

Figure 3. The technological equipment scheme of the cyclic action column

1 - softened water container; $2,16,17$ - centrifugal pumps; 3, 11, 12, 13 - flow-meters;

4 - vacuum breakers; 5 - evaporator; 6 - rectificational column; 7 - dephlegmator; 8 - condenser;

9 - alcohol-collecting vessel (trap); 10 - decanter; 14 - hydraulic shutter; 15 - still residue container; 18 - alcohol-containing fraction collector.

Notation keys: AMC - aldehyde-methanol concentrate; DC - distillation column;

EC - epyurating column; IC - impurities concentrate; DCC - distillation column condenser; CDSC carbon dioxide separator condenser; $\mathrm{SR}$ - still residue; $\mathrm{CW}$ - cooling water; FA - fusel alcohol; FEAC - fusel-ester-aldehyde concentrate; SC - steam condensate; FRW - fusel rinse water; HS heating steam; $\mathrm{HF}$ - head fraction; FL - feed liquid; RW - residue water. 
The $950 \mathrm{~mm}$ diameter $\mathrm{RC}$ was equipped with flaky plates with pivoting sections connected to the pneumatic cylinders and modern computer-integrated means (patent UA 136561. Mass-exchange contact plate) (Figure 4).
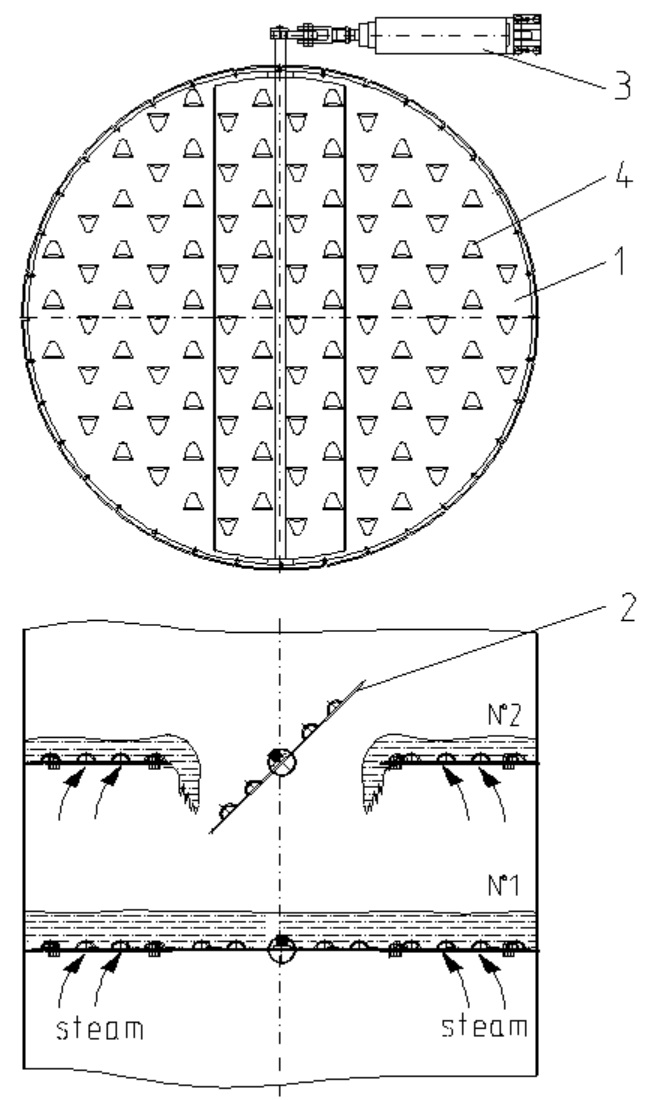

Figure 4. Flaky plate of cyclic action with coaxial placement of flakes and variable free crosssection:

1 - plate fabric; 2 - moving section; 3 - drive mechanism (pneumatic cylinder); 4 - flakes.

The moving sections opened and closed the pouring holes of the plates so that the liquid pouring occurred periodically. The coaxial placement of the flakes made it possible to eliminate the 'one-way' steam and liquid flow and the chance of forming stagnant zones. Pneumatic cylinders and technological parameters operation control (i. e. temperature, pressure) was carried out with the help of automatic sensors, the signal from which was transmitted to the microprocessor controller.

The head fraction of ethyl alcohol, steam condensate from the condensers of the distillation column and carbon dioxide separator, as well as fusel alcohol and fusel rinse water were served on the feeder plate of the column in total amount of $688.3 \mathrm{dm}^{3} / \mathrm{h}\left(250 \mathrm{dm}^{3} / \mathrm{h}\right.$ in terms of anhydrous alcohol (a.a.). The aldehyde-methanol concentrate from the condenser and the fusel-ester-aldehyde concentrate from the upper part of the decanter were sorted to the impurity concentrate collector. 


\section{Research methods}

Liquid consumption. The consumption of alcohol-containing fractions, water for hydroselection, the still residue and rectified alcohol was monitored using PM flow-meters (Yarovenko et al., 1981).

Concentration of ethyl alcohol in water-alcohol solutions. The concentration of ethyl alcohol in the still residue of the RC was determined by areometric method (Polygalina, 1999).

Concentration of volatile alcohol impurities. The concentration of volatile impurities in the head fraction, in the condensate steam from the condensers of the distillation column and carbon dioxide separator, in fusel alcohol, in fusel rinse water and in the feed of the column were implemented on a gas chromatograph with an HP FFAP $50 \mathrm{~m} \times 0.32 \mathrm{~m}$ column (Plutowska et al., 2008; Polyakov, 2007). Three-time repetition samples were taken for chromatographic analysis. The mean values were chosen as the determining ones.

Grade of extraction and concentration ratio of volatile alcohol impurities. The grade of extraction $(\alpha)$ and concentration ratio $(\beta)$ of key organic alcohol impurities were calculated as follows:

$$
\alpha=\frac{X_{f p}}{X_{s r}} ; \quad \beta=\frac{X_{i c}}{X_{f p}} ;
$$

where $X_{f p}, X_{i c}, X_{s r}$ - the concentration of volatile alcohol impurities on the feed plate, impurities concentrate and still residue, $\mathrm{mg} / \mathrm{dm}^{3}$ in terms of a.a. (Shyian et al., 2009).

\section{Studied modes}

It is known, that for flaky plates the lower critical speed of steam in holes, at which liquid spilling stops, is $6,5-7,5 \mathrm{~m} / \mathrm{s}$, linear speed in free cross-section of the column in barbotage mode is $0,5-0,9 \mathrm{~m} / \mathrm{s}$, in transitional $0,9-1,3 \mathrm{~m} / \mathrm{s}$ and in jet 1,3-2,0 m/s. Upper critical speed of steam is $15-16 \mathrm{~m} / \mathrm{s}$ (Stojkovic et al., 2018). Intensive liquid pouring through the holes of the plates occurs at steam velocities of 1.5-1 m/s (Gerven et al., 2009).

Considering the above, the velocity of steam in the holes of flakes during the liquid residence on the plates of the studied $\mathrm{RC}$ was maintained within $12-14 \mathrm{~m} / \mathrm{s}$.

The extraction of ethyl alcohol from alcohol-containing fractions was carried out under the circumstances of moderate and deep hydroselection. Therefore, the upper plate of the column was provided with steam condensate, the temperature of which was $90-92{ }^{\circ} \mathrm{C}$. The condensate consumption was being increased from 2000 to $4500 \mathrm{~m}^{3} / \mathrm{h}$. Yet the concentration of ethyl alcohol in the still residue of the column varied from 2.8 to $8 \%$ vol. Depending on the quantity of liquid, the residence time on the plates was being varied from 20 to $60 \mathrm{~s}$, the pouring time - from 7 to $1.7 \mathrm{~s}$. The height of the liquid layer on the plates was $35-40 \mathrm{~mm}$. Depending on the quantity of alcohol-containing fractions and water for hydroselection the pressure at the bottom of the column was being varied between 12 and $18 \mathrm{kPa}$. For an effective separation of the heterogeneous mixture, the decanter temperature of the RC was being maintained around $30-35^{\circ} \mathrm{C}$ (Shyian et al., 2009). The aldehyde-methanol concentrate and the fusel-ester-aldehyde concentrate were being changed from 12 to $1 \mathrm{dm}^{3} / \mathrm{h}$, while controlling the quality parameters of the RC still residue and rectified ethyl alcohol. 


\section{Stages of research}

At the first stage, the efficiency of the mass transfer process in the typical (Mishchenko et al., 2020) and cyclic (Maleta et al., 2015) rectification in the existing and experimental RC with hydraulic gates was investigated (Figure 1a). The head fraction of ethyl alcohol, steam condensate from the condensers of the distillation column and carbon dioxide separator, as well as fusel alcohol were served on the feeder plate of the column in total amount of 96 $\mathrm{dm}^{3} / \mathrm{h}$ in terms of anhydrous a.a. Heating steam was continuously provided to the lower part of the column and hot softened water - to the upper plate in order to hydroselect the impurities, which ranged the concentration of ethanol in the still residue from $4-5 \%$ vol. The residence time of the liquid on the plates was $23 \mathrm{~s}$ and the pouring time through the hydraulic shutters was $7 \mathrm{~s}$.

At the second stage the efficiency of mass exchange between liquid and steam in an experimental RC of cyclic action without hydraulic shutters was investigated (Figure 1b). The technical solution suggested by the authors provided time-controlled cycles of liquid residence on the plates and its pouring from the upper plates to the lower ones, thanks to instantaneous change of steam velocity in the holes from $12-14$ to $1,5-1 \mathrm{~m} / \mathrm{s}$ by changing free cross-section of the plates from 5,5 to 51,7\%. While the valves were being lifted at the moment the pouring holes were opened, the steam velocity in the holes became lower than critical and the liquid was pouring simultaneously through all the holes to the underlying plates.

At the third stage of the research the optimal parameters of mass exchange process of the experimental RC operation (Figure 3), equipped with flaky plates with turnaround sections, presented in Figure 4. The research included liquid sampling at the feeder plate (FL) as well as samples of the head fraction (HF), fusel alcohol (FA), fusel rinse water (FRW), fractions from the distillation column condenser (DCC) and carbon dioxide separator condenser (CDSC). To determine the efficiency of processing alcohol-containing fractions in a given hydrodynamic mode, the concentration of volatile impurities of alcohol in the still residue (SR), impurities concentrate (IC), epyurate (E), and rectified ethyl alcohol (REA) were studied. The results of the chromatographic analysis of the studied samples are shown in Tables 1 and 2.

\section{Results and discussion}

Study on the efficiency of mass exchange between liquid and steam in RC, equipped with moving valves and plates with hydraulic shutters.

Studies have shown that in the experimental column the esters were completely removed. The grade of extraction of higher alcohols of fusel alcohol and methanol in the cyclic mode increased by $25 \%$, the concentration ratio of head impurities - by $21 \%$, higher alcohols and methanol - by $30 \%$ in comparison with the column operating in the stationary mode. That said, it reduced the specific heating steam consumption by $38 \%$ and $1.2 \mathrm{~kg} / \mathrm{dal}$ of a.a. introduced into the column. This is explained by the fact that when the phase contact time had been prolonged from 13 to $23 \mathrm{~s}$, the difference in concentration of volatile impurities in steam and liquid decreased, thus increasing the grade of phase equilibrium (Bozeya et al., 2013). 


\section{— Food Technology —}

The disadvantages were the low liquid capacity of the column $\left(750 \mathrm{dm}^{3} / \mathrm{h}\right)$, its mixing on adjacent plates during pouring and a $15 \%$ reduction in the working area of the plate due to the presence of the hydraulic shutters.

\section{Study on the efficiency of mass exchange between liquid and steam in RC, equipped with moving valves and plates without hydraulic shutters}

Design changes allowed to increase the liquid throughput by $34 \%\left(750\right.$ to $\left.1000 \mathrm{dm}^{3} / \mathrm{h}\right)$ without reducing the liquid retention time by lessening the pouring time from 7 to $2 \mathrm{~s}$. Due to the absence of hydraulic shutters, the contact area of the phases on each plate has increased by $15 \%$, which has improved the performance of the plates and the efficiency of the mass exchange: the grade of extraction of higher alcohols of fusel alcohol and methanol was increased by $29 \%$, the concentration ratio of aldehydes was increased by $23 \%$, higher alcohols - by $33 \%$ and methanol by $34 \%$ compared to a column operating in stationary mode.

\section{One-stage (full) and two-stage pouring methods}

The one-stage (full) pouring method did not provide an even distribution of liquid on the plates due to a lack of liquid on the paired plates while it being held on the unpaired plates and vice versa (Figure 2a). This technical decision made it impossible to maintain a stable hydrodynamic regime along the height of the column (Chu et al., 2013).

In order to optimize the operation of the $\mathrm{RC}$ and to increase the efficiency of mass exchange, the pouring of liquid from plate to plate was carried out in two stages (Figure 2b). The method allowed to operate all the plates simultaneously, to ensure that the liquid level on the plates is the same throughout the height of the column and to stabilize the hydrodynamic mode of their operation. At that, the RC liquid throughput has increased by $20 \%$ (from 1000 to $1200 \mathrm{dm}^{3} / \mathrm{h}$ ), the grade of extraction of higher alcohols of fusel alcohol and methanol - by $38 \%$, the concentration ratio of head impurities has increased by $25 \%$, higher alcohols - by $38 \%$, methanol - by $37 \%$ compared to a column operating in stationary mode.

The disadvantage of the one- and two-stage methods of liquid pouring is the impossibility of autonomous regulation of liquid residence time on each individual plate, because moving elements of pouring devices of paired and unpaired plates were set in motion by one drive mechanism.

\section{Studies on the efficiency of mass exchange between liquid and steam in RC, equipped with plates with rotary sections}

To eliminate the disadvantages mentioned above, the authors have proposed a method of processing alcohol-containing fractions in a column equipped with plates with rotary sections (patent UA 136560. Method of mass-exchange between liquid and steam in a column apparatus). The results of chromatographic analysis of alcohol-containing fractions entering the column and the distribution of impurities in its still residue, concentrate, epyurate and rectified alcohol are presented in Tables 1 and 2.

The criterion for the RC optimization was the concentration of acetaldehyde, higher alcohols of fusel alcohol (including isopropyl alcohol) and methanol in the still residue and in the rectified ethyl alcohol. The determinants of mass exchange efficiency between liquid and steam were the grade of extraction and concentration ratio of volatile alcohol impurities in the studied RC. 
Results of the chromatographic analysis of alcohol-containing fractions

Table 1

\begin{tabular}{|l|c|c|c|c|c|c|}
\hline \multirow{2}{*}{ Impurity name } & \multicolumn{7}{|c|}{ Concentration, mg/dm } \\
\cline { 2 - 6 } & HF & DCC & CDSC & FA & FRW & FL \\
\hline Ethanol, \% об. & 92,5 & 48,8 & 60 & 89 & 17,5 & 30,5 \\
\hline Aldehydes & 1135,2 & 37,2 & 126,2 & 4,9 & 7,0 & 318,7 \\
\hline Acetaldehyde & 926,1 & 37,2 & 90,9 & 4,9 & 7,0 & 242,3 \\
\hline Methylacetate & 209,1 & traces & 35,3 & traces & traces & 76,4 \\
\hline Esters & 2394,9 & 186,4 & 39,7 & 20,2 & 68,3 & 40,5 \\
\hline Ethylacetate & 2223,6 & 165,8 & traces & 2,1 & traces & trace \\
\hline Isobutylacetate & 23,0 & 13,0 & 7,9 & 10,1 & traces & 11,1 \\
\hline Isoamylacetate & 90,6 & 7,6 & 31,8 & 8,0 & 68,3 & 29,4 \\
\hline Ethylbutyrate & 57,7 & traces & traces & traces & traces & traces \\
\hline Methanol, \% & 0,49 & 0,025 & 0,1445 & 0,013 & 0,0032 & 0,18 \\
\hline Fusel alcohol & 3113,1 & 18820 & 12583 & 48824 & 197726 & 105883 \\
\hline Isopropanol & 4,9 & 4,9 & 1,7 & 1,1 & traces & 1,2 \\
\hline n-propanol & 1186,4 & 1403 & 699,6 & 14741 & 36681 & 20002 \\
\hline Isobutanol & 1640 & 606,1 & 4082 & 27557 & 36826 & 20297 \\
\hline n-butanol & 2,7 & 6,4 & 16,5 & 35 & 705,2 & 362 \\
\hline Isoamylol & 279,1 & 1863,5 & 7783 & 6485,3 & 123514 & 65221 \\
\hline
\end{tabular}

Table 2

Concentration of impurities in the cube liquid, impurities concentrate, epyurate and rectified ethyl alcohol

\begin{tabular}{|l|c|c|c|c|}
\hline \multirow{2}{*}{ Impurity name } & \multicolumn{4}{|c|}{ Concentration, $\mathbf{~ m g / d m}$} \\
\cline { 2 - 5 } & $\mathbf{S R}$ & $\mathbf{I C}$ & $\mathbf{E}$ & REA \\
\hline Ethanol, \% oб. & 3,7 & 67 & 30,1 & 96,5 \\
\hline Aldehydes & 2,8 & 2302,2 & 0,3 & 0,18 \\
\hline Acetaldehyde & 2,8 & 1396,7 & 0,3 & 0,18 \\
\hline Methylacetate & traces & 905,5 & traces & - \\
\hline Esters & traces & 446615 & traces & - \\
\hline Isobutylacetate & traces & 3234,8 & traces & - \\
\hline Isoamylacetate & traces & 494,4 & traces & - \\
\hline Ethylbutyrate & traces & 442886 & traces & - \\
\hline Methanol, \% & 0,004 & 2,69 & 0,0023 & 0,0003 \\
\hline Fusel alcohol & 721,7 & 726464 & 1179,8 & 0,88 \\
\hline Isopropanol & traces & 22,4 & 0,4 & 0,88 \\
\hline n-propanol & 677,5 & 220,6 & 121,4 & - \\
\hline Isobutanol & 4,9 & 357247 & 326,0 & - \\
\hline n-butanol & 2,7 & 1003,8 & 2,0 & - \\
\hline Isoamilol & 13,8 & 367970 & 728,5 & - \\
\hline
\end{tabular}


According to the results of the study, optimal technological parameters of RC operation were:

- the liquid retention time on the plates is $40 \mathrm{~s}$;

- the time of liquid pouring from the upper plate to the lower one is $1.7 \mathrm{~s}$;

- the pressure at the bottom of the column is $11.5-12 \mathrm{kPa}$;

- pressure at the top of the column is up to $0.03 \mathrm{kPa}$;

- the temperature at the bottom of the column is $100.5-101.5^{\circ} \mathrm{C}$;

- the temperature in the steam phase above the upper plate is $93.5-94{ }^{\circ} \mathrm{C}$;

- temperature in the steam phase on the plate of feed is $93.2-94{ }^{\circ} \mathrm{C}$;

- the water temperature for hydroselection is $95-98^{\circ} \mathrm{C}$;

- the temperature of the mixture in the decanter is $30-35^{\circ} \mathrm{C}$;

- water consumption for hydroselection is $4050-4500 \mathrm{dm}^{3} / \mathrm{h}$;

- the temperature in the tube space of the condenser is $45-50{ }^{\circ} \mathrm{C}$;

- water temperature for cooling after the dephlegmator is $85-87^{\circ} \mathrm{C}$;

- concentration of ethyl alcohol in the still residue is 3-4\% vol.;

- withdrawal of aldehyde-methanol concentrate (AMC) from the RC is $7-9 \mathrm{dm}^{3} / \mathrm{h}$;

- concentration of ethyl alcohol in the AMC is $70.5 \%$ vol.;

- withdrawal of the fusel-ester-aldehyde concentrate (FEAC) from the decanter is $2-3 \mathrm{dm}^{3} / \mathrm{h}$.

The calculated values $(\alpha)$ and $(\beta)$ at RC operation in the selected hydrodynamic mode and the specified optimal technical parameters are shown in Table 3.

Table 3

Calculated values of the grade of extraction $(\alpha)$ and concentration ratio $(\beta)$ of volatile alcohol impurities

\begin{tabular}{|l|c|c|c|c|}
\hline \multirow{2}{*}{$\begin{array}{c}\text { Name of } \\
\text { impurities }\end{array}$} & \multicolumn{2}{c|}{ Typical rectification } & \multicolumn{2}{c|}{ Cyclic rectification } \\
\cline { 2 - 5 } & $\boldsymbol{\alpha}$ & $\boldsymbol{\beta}$ & $\boldsymbol{\alpha}$ & $\boldsymbol{\beta}$ \\
\hline Aldehydes & 85,4 & 5,3 & 113,8 & 7,2 \\
\hline Acetaldehyde & 63,7 & 4,3 & 86,5 & 5,8 \\
\hline Methylacetate & $\infty$ & 8,8 & $\infty$ & 11,9 \\
\hline Esters & 79,7 & 8163,7 & $\infty$ & 11027 \\
\hline Isobutylacetate & 57,8 & 214,7 & $\infty$ & 291,4 \\
\hline Isoamylacetate & $\infty$ & 12,3 & $\infty$ & 16,8 \\
\hline Methanol & 27,6 & 9,3 & 45 & 14,9 \\
\hline Fusel alcohol & 89,8 & 4,1 & 146,7 & 6,9 \\
\hline Isopropanol & 87 & 10,9 & $\infty$ & 18,7 \\
\hline n-propanol & 17,9 & 0,005 & 29,5 & 0,01 \\
\hline Isobutanol & 2414,4 & 10,5 & 4142,2 & 17,6 \\
\hline n-butanol & 82,9 & 1,6 & 134,1 & 2,8 \\
\hline Isoamylol & 3953,2 & 3,3 & 4726,2 & 5,6 \\
\hline
\end{tabular}

\section{Result analysis}

Analysis of the obtained results showed that by increasing the contact time of steam and liquid on the $\mathrm{RC}$ plates to $40 \mathrm{~s}$ the grade of extraction and concentration ratio of volatile alcohol impurities increased by $25-38 \%$. At the same time, complex esters, methylacetate and isopropyl alcohol are completely extracted - those are the impurities that significantly 
degrade the quality of rectified alcohol in small amounts. This can be explained by the fact that there was more of a complete steam saturation with it volatile components on the plates of the column and liquid with volatile steam components, the mixing of liquid on adjacent plates during its pouring was excluded, so that the grade of phase equilibrium achievement was increased (Chen et al., 2010; Shyian et al., 1991). The prolonging in the residence time of the liquid on the plates longer than $40 \mathrm{~s}$ proved to be impractical due to an increase in the specific heating steam consumption without a significant increase in the grade of impurity extraction.

Specific consumption of heating steam in experimental RC decreased by $40 \%$ (from 20 to $12 \mathrm{~kg} / \mathrm{dal}$ of a.a. injected to the feed plate) compared to the column operating in the stationary mode. This is explained by the fact that the free cross-sectional area of the plates in the column of cyclic action was 50-75\% smaller than that of the column operating in the stationary mode, and was $2.5-5.5 \%$ (Bausa et al., 2001).

After the experimental distillation column for concentrating impurities was put into operation, the yield of rectified ethyl alcohol increased by $3.8 \%$ due to its extraction from the head fraction and other alcohol-containing waste without deteriorating its qualitative indicators. The use of the RC liquid purified from volatile impurities for carrying out hydroselection in the epyurating column made it possible to reduce the consumption of hot softened water by $2000 \mathrm{dm}^{3} / \mathrm{h}$ (patent UA 119277. Method of producing rectified alcohol; Ukrainets et al., 2006).

\section{Conclusion}

1. To increase the efficiency of mass exchange between liquid and steam in rectification columns the expediency of using a cyclic rectification technology that provides periodic pouring of liquid from plate to plate at continuous supply of alcohol-containing fractions and steam in the column is proved.

2. To implement the technology, the plates have to be equipped with moving sections connected to driving mechanisms (e.g., pneumatic cylinders), which are controlled according to the program of the controller in consonance with a predetermined algorithm.

3. Equipping the columns with flaky plates allows to increase their capacity by $34 \%$ due to intensification of liquid pouring by doing so simultaneously through the pouring and barbotage holes.

4. At the moment of liquid pouring, steam velocity in barbotage holes should be 1,5-1 $\mathrm{m} / \mathrm{s}$. At this speed the pouring occurs within $1.7 \mathrm{~s}$.

5. To ensure stable operation of the plates during the period of liquid retention and in order to intensify its pouring, their free cross-section area should instantly change from 5.5 to $51.7 \%$.

6. In working environment, the optimal technological parameters of column operation of cyclic action were established. It is experimentally proven, that prolonging the contact time of steam and liquid up to $40 \mathrm{~s}$ allows to increase the grade of extraction and concentration ratio of volatile impurities of alcohol by 25-38\% compared to a column operating in stationary mode. In doing so, the complete extraction of esters, methylacetate and isopropyl alcohol is provided.

7. The coaxial placement of the flakes on the plate fabric allows to eliminate the possibility of formation of stagnant zones and intensify the mass transfer between steam and liquid. 
8. The use of innovative technology makes it possible to reduce the specific consumption of heating steam during processing of alcohol-containing fractions by $40 \%$ compared to the known ones.

9. It is advisable to use the results of the research to design column mass exchange apparatuses of cyclic action.

\section{References}

1. Ayat Bozeya, Abeer Al-Bawab, Stig E. Friberg \& Clarence A Miller. (2013), Spontaneous Emulsification and Phase Equilibria in the System Water, Ethanol, and Benzene, Journal of Dispersion Science and Technology, 34(10), pp. 1429-1436.

2. Bastian B. Andersen, Rasmus F. Nielsen, Isuru A. Udugama, Emmanouil Papadakis, Krist V. Gernaey, Jakob K. Huusom, Seyed Soheil Mansouri, Jens Abildskov (2018), Integrated Process Design and Control of Cyclic Distillation Columns, IFACPapersOnLine, 51(18), pp. 542-547.

3. Bausa J., Tsatsaronis G. (2001), Reducing the energy demand of continuous distillation processes by optimal controlled forced periodic operation, Computers \& Chemical Engineering, 25, pp. 359-370.

4. Buliy Y., Shiyan P., Kuts A., Melnic I. (2019), Technology of cyclic rectification of alcohol production, Journal of Food Science and technology, 13, pp. 104-111.

5. Buliy Y., Shiyan P., Kuts A. (2016), Distillation of alcoholic distillate in controlled cycles mode, Food Science for Well-being (CEFood 2016): 8th Central European Congress on Food 2016, Kyiv, NUFT, p. 230.

6. Bulii Yu.V., Kuts A.M., Shyian P.L. (2019), Pidvyshchennia ekspluatatsiinykh kharakterystyk masoobminnykh kolonnykh aparativ tsyklichnoi dii, Zhurnal Naukovi pratsi NUKhT, 25(5), pp. 48-54.

7. Chen H., Huang K., Wang S. (2010), A novel simplified configuration for an ideal heatintegrated distillation column (ideal HIDiC), Separation \& Purification Technology, 73, pp. 230-242.

8. Chu G. W., Gao X., Luo Y., Zou H. K., Shao L., Chen J. F. (2013), Distillation studies in a two-stage counter-current rotating packed bed, Separation \& Purification Technology, 102, pp. 62-66.

9. Flodman H. R., Timm D.C. (2012), Batch distillation employing cyclic rectification and stripping operations, ISA Transactions, 51, pp. 454-460.

10. Jess Bjørn Rasmussen, Seyed Soheil Mansouri, Xiangping Zhang, Jens Abildskov, Jakob Kjøbsted Huusom (2020), A mass and energy balance stage model for cyclic distillation, AIChE Journal, 66(8), pp. 1002.

11. Kyziun H.O., Mishchenko O.S., Mikhnenko Ye.O. i inshi (2006), Enerhozberezhennia na brahorektyfikatsiinykh ustanovkakh, Koleha, NUKhT, 6-8, pp. 52-54.

12. Kiss AA, Flores Landaeta SJ, Edvin Zondervan CJ. (2012), Cyclic distillation- towards energy efficient binary distillation. Chemical Engineering and Chemistry, 30, pp. 697701.

13. Kiss AA, Olujic Z. (2014), A review on process intensification in internally heatintegrated distillation columns, Chem Eng Process, 86, pp. 125-144.

14. Kiss A. (2015), Pilot-scale studies of process intensification by cyclic distillation // AIChE Journal, 61, pp. 2581-2591. 
15. Kiss A.A., Bildea C.S. (2011), A control perspective on process intensification in dividing-wall columns. Chemical Engineering and Processing: Process Intensification. 50(3), pp. 281-292.

16. Kiss A. (2015), Pilot-scale studies of process intensification by cyclic distillation, AIChE Journal, 61, pp. 2581-2591.

17. Kiss A.A. (2014), Distillation technology - still young and full of breakthrough opportunities, J Chem Technol Biotechnol, 89, pp. 479-498.

18. Krivosheev V., Anufriev A. (2015), Fundamentals and efficiency of cyclic modes of rectification process. Basic Research, Scientific Journal of Basic Research, 11(2), pp. 267-271.

19. Lita I., Bildea C. S., Kiss A. A. (2012), Modeling, design and control of cyclic distillation systems, Procedia Engineering, 42, pp. 1311-1322.

20. Maleta V.N., Kiss A.A., Taran V.M., Maleta B.V. (2011), Understanding process intensification in cyclic distillation systems. Chemical Engineering and Processing: Process Intensification, 50(7), pp. 655-664.

21. Maleta B.V., Taran V.N., Maleta V.N. (2010), Spivstavlennia tsyklichnoho ta statsionarnoho protsesu rektyfikatsii, Naukovi pratsi NUHT, 33, pp. 95-97.

22. Maleta B., Taran V., Maleta V. (2010), Energy-saving technology of mass transfer in tray columns with separate phase movement, The 6 th European Meeting on Chemical Industry and Environment EMChIE (Mechelen, Belgium), Conference Proceeding, 2, pp. 1149-1155.

23. Maleta B.V., Shevchenko A., Bedryk O., Kiss A.A. (2015), Pilot-scale studies of process intensification by cyclic distillation, AIChE Journal, 61, pp. 2581-2591.

24. Marija Stojkovic, Vincent Gerbaud, Nataliya Shcherbakova. (2018), Cyclic operation as optimal control reflux policy of binary mixture batch distillation, Computers \& Chemical Engineering, 108, pp. 98-111.

25. Martseniuk O.S. Malezhyk I.F., Zotkina L.V. (2019), Tarilchasti aparaty ta yikh udoskonalennia, Zhurnal Naukovi pratsi NUKhT, 25(2), pp. 121-133.

26. Mishchenko O. S., Kyziun H. O., Mozharovska A. A., Oliinyk S. I. (2020), Enerhoefektyvna tekhnolohiia pererobky fraktsii holovnoi etylovoho spyrtu $\mathrm{Z}$ otrymanniam spyrtu etylovoho rektyfikovanoho, Naukovyi zhurnal Kharchova promyslovist, NUKhT, 28, pp. 115-122.

27. Pătruţ C, Bîldea CS, Liţă I, Kiss AA. (2014), Cyclic distillation- design, control and applications. Separation and Purification Technology, 125, pp.326-336.

28. Plutowska B., Wardenski W. (2008), Application of gas hromatography-olfactometry (GC-O) in analysis and quality assessment of alcoholic bewerages- a review, Food Chemistry, 107, pp. 449-463.

29. Polyakov V.A. (2007), Instrukciya po tekhnohimicheskomu i mikrobiologicheskomu kontrolyu spirtovogo proizvodstva, DeLi print, Moscow.

30. Polygalina G.V. (1999), Tekhnohimicheskij kontrol' spirtovogo i likero-vodochnogo proizvodstva, Kolos, Moscow.

31. Rasmus Fjordbak Nielsen, Jakob Kjøbsted Huusom, Jens Abildskov, Driving Force Based (2017), Design of Cyclic Distillation, Industrial \& Engineering Chemistry Research, 56(38), pp. 10833-10844.

32. Shyian P.L., Sosnytskyi V.V., Oliinichuk S.T. (2009), Innovatsiini tekhnolohii spyrtovoi promyslovosti. Teoriia i praktyka: Monohrafiia, Vydavnychyi dim Askaniia, Kyiv.

33. Shiyan P.L., Tsygankov P.S., Buliy Yu.V., Mozgovaya O.I. (1991), Fazovoe ravnovesie $\mathrm{v}$ sisteme etanol-voda pri davleniyakh nizhe atmosfernogo (soobshchenie II). 
Eksperimental'nye issledovaniya i termodinamicheskaya proverka rezul'tatov, Zhurnal «Izvestiya vuzov. Pishchevaya tekhnologiya», 1(3), pp. 114-116.

34. Toftegard B., Clausen C.H., Jorgensen S.B., Abildskov J. (2016), New Realization of Periodic Cycled Separation, Ind. Eng. Chem. Res, 55(6), p. 1720.

35. Ukrainets A., Shiyan P., Buliy Y., Kuts A. (2018), Increasing the efficiency of the distillation unit, Scientific Works of National University of Food Technologies, Kyiv, NUFT, 24(6), pp. 160-166.

36. Ukrainets A.I., Shyian P.L., Sosnytskyi V.V. (2006), Perspektyvni napriamky enerhozberezhennia $\mathrm{v}$ spyrtovomu vyrobnytstvi, Zhurnal Kharchova $i$ pererobna promyslovist, 4, pp. 4-12.

37. Van Gerven T., Stankiewicz A. (2009), Structure, energy, synergy, time-the fundamentals of process intensification, Ind Eng Chem Res, 48, pp. 2465-2474.

38. Yarovenko V.L., Ustinnikov B.A., Bogdanov YU.P., Gromov S.I. (1981), Spravochnik po proizvodstvu spirta, Legkaya i pishchevaya promyshlennost', Moscow. 